\title{
WOULD A SUSTAINABLE CITY BE SELF-SUFFICIENT IN FOOD PRODUCTION?
}

\author{
GASTON E. SMALL ${ }^{1, *}$, ROBERT MCDOUGALL ${ }^{2}$ \& GENEVIÈVE SUZANNE METSON ${ }^{3}$ \\ ${ }^{1}$ Biology Department, University of Saint Thomas, Saint Paul, Minnesota, United States. \\ ${ }^{2}$ School of Environmental and Rural Sciences, University of New England, Armidale, NSW, Australia. \\ ${ }^{3}$ Department of Physics, Chemistry, and Biology (IFM), Linköping University, Linköping, Sweden.
}

\begin{abstract}
Urban agriculture has increased in many cities and has the potential to provide an array of benefits including increased local food production, nutrient recycling, urban green space, and biodiversity. While certain environmental benefits of urban agriculture are evident, it is not clear what the optimal extent of urban agriculture would be in designing a sustainable city. Closing the loop by recycling waste products into new resources is fundamental to sustainability, but the extent to which this should occur at local, regional, or global scales is an open question. We analyze how potential benefits and costs associated with urban agriculture scale with the extent of implementation, and compare potential tradeoffs in different metrics of sustainability. We assess how the appropriate metrics to optimize in a given city are context-dependent. For example, maximizing production in a small land footprint could be important in densely developed urban environments, whereas filling vacant land with food-producing gardens may be a more appropriate goal in certain post-industrial cities. We assess the potential role that urban agriculture plays in making urban food systems more resilient to climate change and other disruptions. Finally, we consider a case study comparing the resources required and pollution generated to produce the lettuce supply of on U.S. metropolitan area through outdoor urban agriculture and indoor urban agriculture, compared to conventional production and cross-continental transportation. This analysis illustrates the importance of considering multiple metrics in assessing sustainability of urban agriculture. Keywords: cost-benefit analysis, sustainability, resilience, trade-offs, urban agriculture.
\end{abstract}

\section{INTRODUCTION}

'A good way to see the embedding problem is to imagine the consequences of cutting off all flows in and out, as military sieges of European castles and cities attempted to do in the Middle Ages. From this point of view and in the short term of days to months, some farms and ranches would be reasonably sustainable, but the residents of a large city or an apartment building would rapidly succumb to thirst, starvation, or disease. Viewed from this perspective, even though Portland may be the greenest and by some definitions 'the most sustainable city in America', it is definitely not self-sustaining.' [1]

The quote above highlights the degree to which cities are open ecosystems, depending on imports of food and other materials, and exportation of waste. A city cut off from its food supply, whether by an invading army or a natural disaster, quickly descends into chaos. This passage also raises questions about the relationship between self-sufficiency and sustainability. Would a sustainable city be self-sufficient in food production? Should urban planners strive towards maximizing urban food production in the name of sustainability, or might economic, social, and environmental costs exceed benefits at some point? While the recent growth of urban agriculture (UA) has provided social and environmental benefits, resources required (e.g. space, labor, water, energy) and pollution generated (e.g. nutrient-laden runoff) could eventually present barriers to continued expansion. These potential tradeoffs add complexity to understanding the role of urban agriculture in sustainability.

\footnotetext{
* ORCHID: http://orchid.org/0000-0002-9018-7555
} 
Cities generally require a total land area that is 200-300 times larger than the geographic footprint of the city itself to provide food and other resources, and to assimilate wastes [2]. Historically in the United States, much food production for cities occurred in the surrounding hinterlands, but the industrialization of agriculture in the 20th Century and growth of transportation infrastructure has led to long supply chains. One study estimated the average direct transport distance of food in the United States to be $1,640 \mathrm{~km}$, and this distance stretches to over $6,000 \mathrm{~km}$ if the entire supply chain is taken into account [3]. The long-distance movement of food has added to the environmental footprint of food production through raising transportation-related $\mathrm{CO}_{2}$ emissions [4]. However, the majority of greenhouse gas emissions are associated with crop production rather than transportation [3], and a nationwide or global food production network allows crops to be grown in areas where resource supply (climate, water, labor) is favorable. Local production may not be inherently more sustainable, despite common assumptions [5].

The expansion of UA in recent years provides a range of potential social, economic, health, and environmental benefits to urbanites [6]. UA has potential environmental benefits including reduction of transportation-related energy consumption [7], creating habitat for pollinators [8], reducing urban heat island effect [9], and providing a beneficial reuse for wastewater and organic matter $[10,11]$. Potential social benefits include strengthening connections between farmers and consumers [12], connecting urban residents with nature [13, 14], and improving livability of cities [15-17]. Potential public health benefits include lowering disease risk due to adoption of more plant-based diets [18, 19], as well as benefits to general well-being [20, 21]. Potential economic benefits of UA include stimulating green-sector employment [22] and improving food access to low-income residents [23].

However, many of these benefits are also coupled with challenges [6]. For example, while UA may create green jobs, it often relies on underpaid labor, and commercial UA jobs that earn a living wage are rare relative to the number of students who are being trained for potential careers in this field [23]. While UA may increase urban property values in some localities [24], other studies have found limited economic impacts [25]. While UA can reduce greenhouse gas emissions related to transportation and storage [26], it may lead to increased emissions from climate-controlled local food production [27]. While UA can result in increased urban nutrient recycling through the use of compost, nutrient recycling efficiency may often be very low $[28,29]$ resulting in nutrient loss to groundwater and surface water $[30,31]$. While UA systems may provide a more valuable habitat for urban biota than lawns or other common urban land uses [32], urban wildlife populations may be too depauperate to take advantage of this improved habitat [33]. Land used for UA may have other beneficial uses, presenting opportunity costs for local food production. Furthermore, different types of UA (e.g. backyard gardens, rooftop gardens, vertical farming) require different resources and provide different benefits [6]. While the cumulative potential value of ecosystem services provided by UA has been estimated as high as 160 billion USD [34], the exact nature of these benefits (and costs) is highly dependent on the context of a particular city [6, 35].

\section{OBJECTIVES AND METHODOLOGY}

In order to evaluate the optimal extent of UA in a given urban area, a holistic analysis of social and environmental benefits and costs is required. In this paper, we first evaluate the production potential of urban agriculture by compiling values reported from various case studies. We examine potential metrics of sustainability in UA and explore potential trade-offs among these metrics. We present a conceptual model as a framework for considering which metrics 
of sustainability should be optimized in various contexts. We analyze how potential benefits and costs associated with UA scale with the extent of implementation, and we evaluate the potential role that UA may play in making urban food systems more resilient by reviewing relevant case studies. Finally, we present an original case study examining the economic and environmental costs of producing the lettuce supply for Minneapolis-Saint Paul, Minnesota, from either outdoor or indoor UA, compared to importation from central California.

\section{PRODUCTION POTENTIAL OF URBAN AGRICULTURE}

For UA production to fulfill global urban vegetable demand would require one-third of all urban spaces [36], although this analysis does not account for the likely extensive variation among cities. Many cities in mild climate zones have the potential for UA to fulfill a substantial fraction of urban fruit and vegetable demand under intensive outdoor production scenarios (Fig. 1). However, most urban crops are generally low in calories so that even these highproduction scenarios are not contributing a significant amount of food calories. There is precedent for urban vegetable self-sufficiency: the Paris market gardens of the late 19th Century covered $1 / 6$ of the city's land area and provided more than $100 \%$ of the city's demand for salad crops (but only $1.4 \%$ of caloric requirements, and $2.4 \%$ of protein requirements [37]). If peri-urban agriculture is included, the capacity for local self-sufficiency increases considerably. Twenty-one percent of U.S. metropolitan statistical areas (MSAs) are currently capable of local self-sufficiency for milk and eggs, $12 \%$ of MSAs are capable of local self-sufficiency for fruit, and 16\% of MSAs are capable of local self-sufficiency for vegetable production [38].

If the sustainability of UA is to be fully assessed, the assumptions underlying these production scenarios should be critically examined. For example, several UA production scenarios involve extensive use of industrial and commercial rooftops [39-41]. In some cases, rooftops would need to be retrofitted to handle the additional weight [40], which could pose a significant expense, and the potential need for irrigation and potential nutrient pollution from

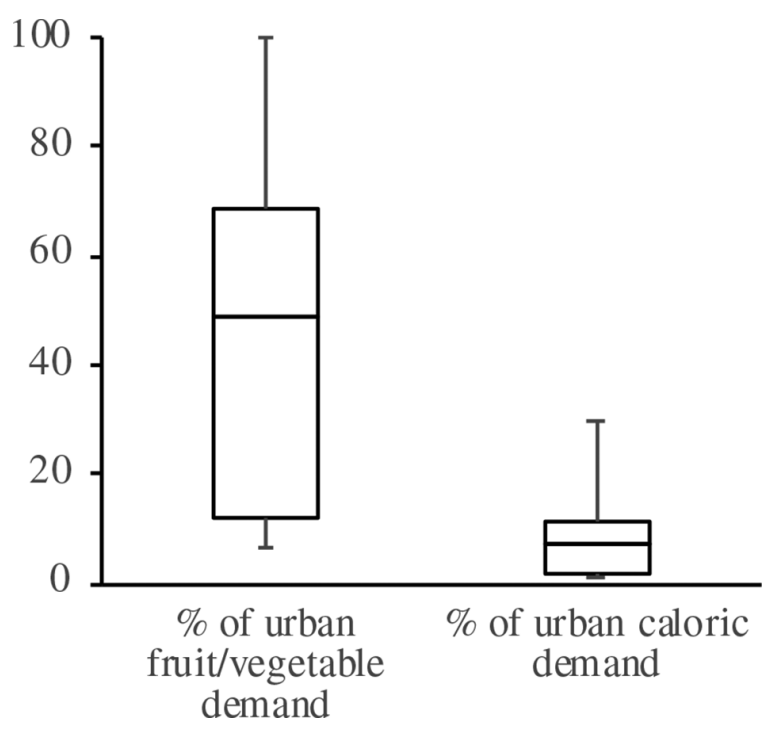

Figure 1: Percent of urban fruit and vegetable production demand ( $\mathrm{n}=8$ cities), and percent of urban caloric demand ( $\mathrm{n}=12$ cities), potentially supplied by urban agriculture under intensive outdoor production scenarios. Data are from [6, 39, 40, 90-100]. 
rooftop runoff [42] would need to be weighed against the economic, social, and environmental benefits of this expanded urban food production. Other intensive UA production scenarios assume extensive cultivation of available vacant land and some fraction of residential land [6, 39]. Under these scenarios, the intensive human labor requirement [43] and the potential for nutrient pollution from compost application [31] should be considered along with the direct benefits of food production plus indirect benefits such as providing pollinator habitat, fostering civic engagement, and promoting public health [6]. While proponents of indoor vertical farms offer a more expansive vision of urban food production, such as 30-story farms on a city block that could feed 50,000 people with vegetables, fruit, eggs, and meat [44], evidence supporting the economic and environmental feasibility of this vision are lacking.

\section{TRADEOFFS AMONG METRICS OF SUSTAINABILITY}

Many UA practitioners cite environmental benefits or sustainability as a key motivating factor [43]. UA has been characterized as resource-efficient based on use of vacant space, potential use of stormwater for irrigation, and reduction of food miles [45]. However, UA can be inefficient in terms of human labor [43] and nutrient recycling efficiency [29, 31]. Assessing the environmental sustainability of UA requires consideration of a wide variety of metrics, such as: biomass yield per unit area; calories or protein yield per unit area; yield per human energy input; yield per fossil fuel energy input; yield per unit input of nutrients or water; yield per pollution generated; output value relative to input value; net profit per unit area; net profit relative to capital inputs; the use of recycled nutrients; and the provisioning of pollinator habitat or other ecosystem services.

It is likely that there are tradeoffs among some of these metrics. For example, maximizing yield per unit area may require additional inputs of water, fertilizer, and labor, which could reduce the efficiency in terms of those metrics. Maximizing profitability may require production of fast-growing leafy greens or herbs, rather than in crops higher in calories or protein. Indoor production can achieve high yields and high efficiency of space, water, and nutrient use, but this type of UA typically requires high capital inputs and does not recycle nutrients from urban waste or provide habitat for pollinators and other urban biota. Determining which metric to optimize is context-dependent, based on resource availability in a given city, or for a given producer. In a densely populated urban area such as Brooklyn, optimizing the spatial footprint of UA (e.g. through rooftop farming) may be a top priority, whereas in post-industrial cities such as Cleveland or Detroit, where vacant lots are abundant, space may not be a constraint. In water-stressed cities such as Los Angeles, optimizing water use in UA may be a higher priority than in cities like Seattle that receive ample rainfall. Sustainability requires optimizing the use of the scarcest resource.

A conceptual framework for evaluating sustainability of UA is shown in Fig. 2. Urban agriculture creates the potential for local food production fueled by recycled organic waste and water. Like all forms of agriculture, UA requires inputs of energy, labor, space, water, and nutrients, and generates desired outputs (crop yield) as well as undesired outputs (pollution). The availability of these resources is represented by the cost to UA practitioners, or, for some resources in the case of outdoor UA production (sunlight, ambient rainfall, temperature range), is determined by climate zone. Inputs required for UA such as nutrients and water may have high amounts of embedded energy, or fossil fuel used in the production chain of these resources [46]. The environmental impact of nutrient pollution from urban gardens depends on the capacity of the local soils to retain (e.g. through adsorption of phosphorus) and remove (e.g. through microbial denitrification) these nutrients, and the sensitivity of downstream aquatic ecosystems that would receive these nutrients. There are both opportunities to 

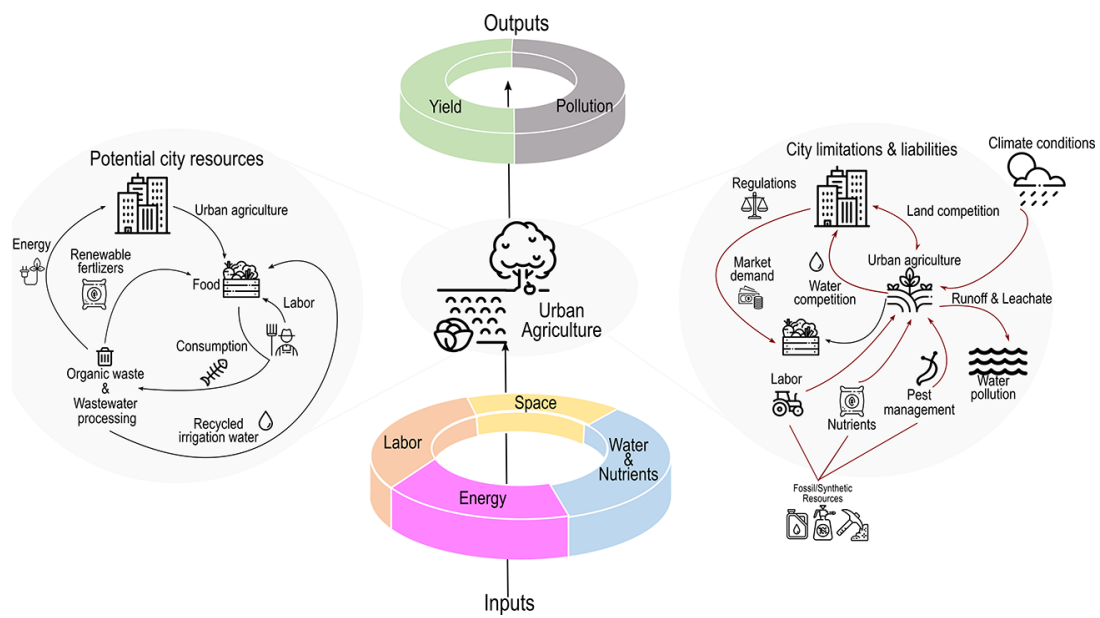

Figure 2: Conceptual diagram for evaluating sustainability of Urban Agriculture (UA), focused on material and economic flows. Center panel: UA requires inputs of labor, energy, space, water, and nutrients, and generates both desired outputs (crop yield) and undesired outputs (pollution). UA presents potential opportunities to sustainably acquire inputs and manage outputs (left circle), but also poses multiple constraints and potential sustainability trade-offs (right circle).

sustainably acquire inputs and manage outputs, but cities also face multiple constraints and potential sustainability goal trade-offs that can arise from UA. UA creates potential to help close the material cycling loop in cities through use of recycled nutrients and water to provide food, and be compatible with green energy harvesting from organic waste. It can also provide other circular economy benefits like employment. However, not all cities have the space, money, or growing conditions to support intensive UA without damaging social and ecological resources.

The economic feasibility of UA can also be assessed through this framework. While net economic benefit may be of small concern to many home gardeners [6, 43], larger-scale UA (i.e. urban farms) must be profitable to exist, unless supported by cities, universities, or other entities. Gross revenue from crop production depends on crop yield and crop value, which depends on the local market. Scaling up local food production could saturate market demand and depress prices. Production costs include costs of inputs (fertilizer, water, pesticide, energy for indoor growing), labor, and the cost of processing, transporting, and distributing crops. Additionally, the cost of land/space and any capital costs for equipment must be factored in.

Different forms of UA generally require different amounts of resources and generate different amounts of yield and pollution. Outdoor UA utilizing raised beds is one of the most common types of UA [47]. Yield can be high relative to conventional rural agriculture due to intercropping and planting at a higher density than mechanized agriculture allows for, but human labor inputs are also very high [37, 43]. Non-solar energy inputs are minimal, and required supplemental water inputs depend on local climate. However, there is potential for nutrient pollution due to runoff or leachate, depending on the type and quantity of compost or other soil amendments applied $[31,28]$. Capital cost is generally very low, and this type of UA can be implemented on residential lawns or vacant lots, so space may not be a limitation except in high-density urban developments (Fig. 3). 

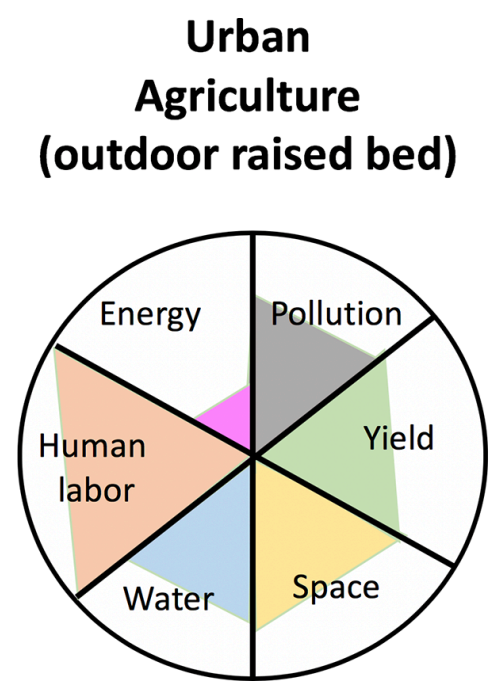
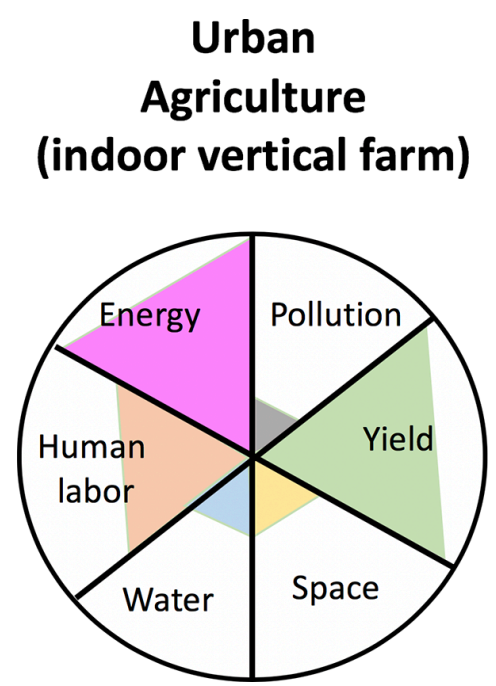

Figure 3: Relative magnitudes of inputs (Energy, Human Labor, Water, Space) and outputs (Yield, Pollution) from outdoor and indoor urban agriculture.

In contrast, indoor vertical farms typically use hydroponics systems and artificial light to grow crops, and can achieve extremely high yields per unit area by growing up to 8 crop cycles per year [48] and stacking multiple vertical layers of growing beds. One hectare of hydroponic greenhouse production has the potential to replace 10 hectares of rural land [41]. Commercial tomato production in greenhouses can achieve yields up to 15 times higher than outdoor growing [49], and indoor farms or rooftop greenhouses in New York City report yields of lettuce greens that are approximately 30 times higher compared to conventional outdoor production [23]. Water use in indoor growing systems is highly efficient, $75 \%$ lower than conventional farming [50]. Indoor production systems have the potential to recycle water transpired by crops [51], harvest rainwater [50], or utilize graywater [52]. Most indoor UA production systems have a high non-solar energy requirement for heat and lighting, although the use of waste heat from buildings can reduce this requirement [53]. However, the amount of $\mathrm{CO}_{2}$ generated per $\mathrm{kg}$ of vegetable produced may be $2-5 \mathrm{x}$ greater than for produce grown outdoors [4, 27], exceeding $\mathrm{CO}_{2}$ emissions from cross-country transport of crops [54]. Human labor required may vary depending on the degree of mechanization of the indoor growing operation [23]. While hydroponics systems may not be a source of nutrient pollution, they also do not usually recycle waste nutrients, instead relying on inputs of industrially derived nutrients to maintain high yields [55]. Indoor UA production also does not provide environmental benefits such as pollinator habitat, or social benefits of urban residents being in contact with gardens. Because of the high capital requirements [56] and complex profit model [57] of commercial indoor production, production tends to focus on salad greens and herbs that can be sold for premium prices, and therefore are not accessible to many low- and middle-income consumers [23].

\section{SCALE AND SUSTAINABILITY}

In addition to differences between indoor and outdoor UA systems, the scale of UA production is also likely to affect metrics of sustainability. For example, human labor efficiency may be extremely low in backyard gardening, where production and efficiency are generally not 
motivating factors of these gardeners [43], however some of this apparent inefficiency may be due to gardeners mixing recreational activities with labor [58]. For larger scale commercial urban farms, efficient use of labor may be necessary to maintain viability. UA is generally able to achieve higher yields per unit area compared to conventional agriculture due to intercropping and polyculture, which depends on human labor. At larger scales (where labor, rather than space, becomes a limiting factor), mechanization replaces human labor and necessitates a shift from polyculture to monoculture [59].

Nutrient use efficiency is likely to increase with increasing scale. For backyard gardeners, there is little economic incentive to be judicious in use of fertilizer or compost, and extremely high fertilizer use has been documented in some urban food gardens [60]. For larger area operations, the cost and labor required to apply fertilizer or other soil amendments creates incentives to actively manage soil fertility in response to soil test results. This relationship is illustrated by the relatively high nitrogen-use efficiency (20-70\% [61]) and phosphorus-use efficiency (60-100\% [62]) for conventional agriculture, compared to values below 5\% that have been documented for outdoor, soil-based UA [29, 31, 28]. The use of other resources such as water is also likely to become more efficient in larger scale production systems.

However it is worth noting that, depending on the source of the material in question, higher levels of some inputs could in fact improve the sustainability of UA systems. This could be the case with amendments based on organic waste material, such as compost or mulch. Organic material, such as food scraps and garden waste, forms a major part of the domestic waste stream of many cities in developed nations [63], much of it going to landfill, resulting in the emission of greenhouse gases both as a result of its management and decomposition. It could thus be argued that increasing inputs of these materials into UA could be of benefit to the environment and economy of the city in which it occurs, even if they are in excess of what is needed, so long as they don't exceed the ecological carrying capacity of the system. The same is true of water, which, if captured as run-off from impervious surfaces, can reduce erosion and contamination of nearby water bodies [64].

\section{URBAN AGRICULTURE AND RESILIENCE OF URBAN FOOD SYSTEMS}

In times of crisis UA has provided a number of direct benefits to urban citizens in terms of access to food and green space, but also continues to play a role in collective memories and skills about how to grow food and create communities [65]. For example, Stockholm's allotment gardens participants have meaningful communities of practice where people learn from each other about ecosystem services and reflexively adapt to changing circumstances [66]. The expansion of UA has potential to make urban food systems more resilient, by reducing reliance on external imports during times of scarcity. For example, in the United States during World War II, half of all families planted Victory Gardens, producing $55 \mathrm{~kg}$ of fruit and vegetables annually for every civilian [67]. In Cuba, following the fall of the Soviet Union, the caloric intake of Cubans dropped nearly $30 \%$, and the government instituted a goal of cultivating $10 \mathrm{~m}^{2}$ of urban land for every resident. By 2000, Cuba surpassed pre-crisis levels of food production, and these urban farms provided up to $50 \%$ of caloric intake and reduced the need for imported fuel to distribute food and generate electricity for refrigeration [68]. Beyond political disasters, climate change, and especially extreme weather events, can threaten food supply chains [69]. Local production from UA can serve as a buffer to climate-related disruptions [70] or other external disruptions, such as sharp increase in fossil fuel costs. On the other hand, the effects of climate change on UA production could be positive (e.g. by increasing the length of the outdoor growing season in some cooler-climate cities) or negative (e.g. by increasing frequency of 
severe droughts in some areas). If climate change leads to increasing scarcity of water in some cities, then the cost (both economic and environmental) of UA would increase correspondingly. While UA may help decrease urban heat island effects through evaporative cooling [71], water is the currency required for this ecosystem service, and climate change may drive this cost to increase in the future. For example, recent research in Melbourne, Australia, has found that urban gardeners have increased water use to adapt to increased temperatures (related to climate change and exacerbated by the urban heat island effect), which could be a maladaptation if there is water scarcity [72]. On the other hand, inefficiencies in water use that might occur when practicing UA can offer a 'buffer' when resources are scarce, providing resilience in terms of food, water, and even energy as in past civilizations like the Mayan and Byzantine empires [73].

It is also possible that increased reliance on UA could lead to potential vulnerabilities in food supply. Outdoor production could be susceptible to extreme weather events and pest outbreaks. Indoor production is susceptible to disruptions from power outages. There have been numerous documented instances of short-term power outages destroying aquaponics or hydroponics crops [74-76]. Backup generators provide a buffer to short-term power disruptions, but during extended disruptions (e.g. power outages associated with Hurricane Maria in Puerto Rico in 2017), there may be more pressing needs for fuel and electricity than keeping plants or fish alive.

\section{CASE STUDY: LETTUCE PRODUCTION IN MINNEAPOLIS-SAINT PAUL, USA} We will consider a scenario of a major U.S. metropolitan area, Minneapolis-Saint Paul, becoming self-sufficient for one vegetable crop, lettuce. Lettuce production is the leading U.S. vegetable crop in terms of value, generating nearly $\$ 2$ billion worth of product annually [77]. California and Arizona account for nearly all commercial lettuce production (both head and leaf lettuce) in the U.S. [77], but lettuce is also a common UA crop that is grown both indoors and outdoors. Minneapolis and Saint Paul have a combined population of 730,000 [78], and Americans consume an average of $2.63 \mathrm{~kg}$ of lettuce annually [77], resulting in an estimated annual lettuce demand of 1900 metric tons for Minneapolis and Saint Paul.

\subsection{Importing lettuce from California}

Because California accounts for over $70 \%$ of U.S. lettuce production, we will first consider the economic and environmental costs of importing lettuce from Monterey County, California. Lettuce yields on the California Central Coast exceed 46,000 kg/ha [79], resulting in a land requirement of 41.7 ha to meet the demand for Minneapolis-Saint Paul. The human labor requirement for this lettuce production comes to nearly 21,000 person-hours, mostly during harvest [79]. The estimated water requirement for irrigating the lettuce crop is $380,000 \mathrm{~m}^{3}$ [80]. Including transportation, the total $\mathrm{CO}_{2}$ emissions from lettuce production and distribution are approximately $1,770,000 \mathrm{~kg}$ [80] (Fig. 4). The total cost of production and distribution is approximately $\$ 1.2$ million $[79,81]$.

\subsection{Outdoor UA lettuce production}

If the 1900 metric tons of lettuce were to be produced entirely through outdoor UA, it would require approximately 21 hectares of land, assuming two crops are produced annually (this calculation assumes that the entire year's lettuce supply would be produced during the ca. 5-month growing season, ignoring storage constraints). Minneapolis alone has over 


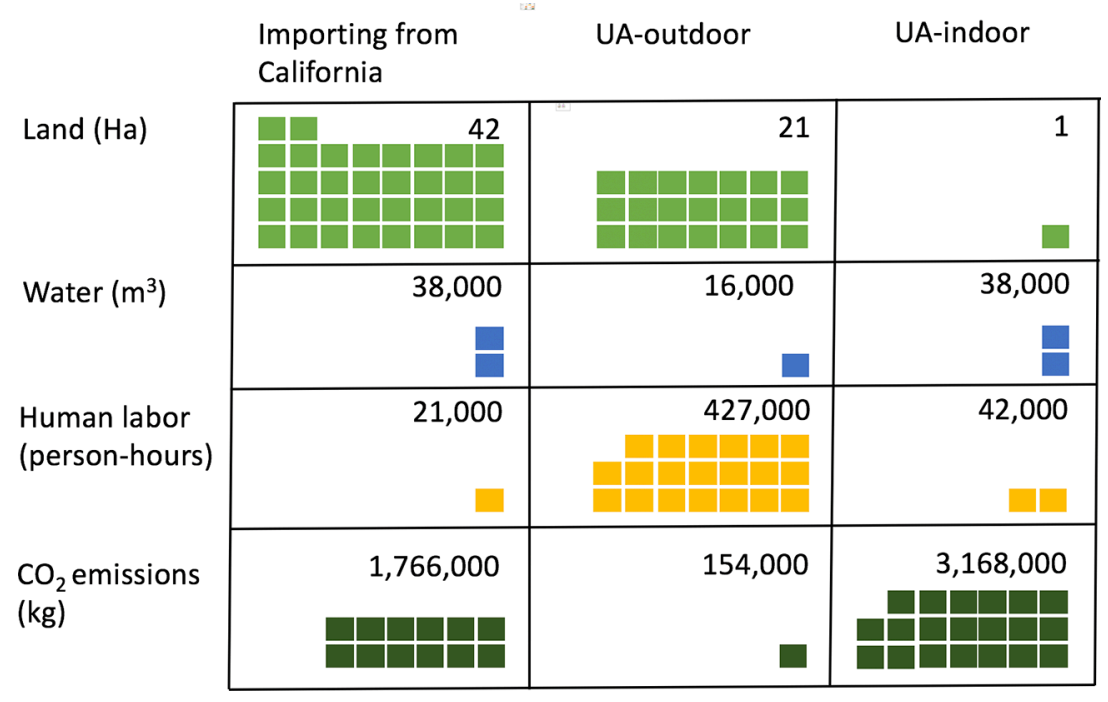

Figure 4: Estimated resources required, and pollution generate, in order to supply lettuce for the Twin Cities from importing from California, local outdoor UA production, and local indoor UA production.

315 hectares of vacant land [82], so the space requirement is not a limitation. This lettuce production would require approximately $16,000 \mathrm{~m}^{3}$ of irrigation water to supplement average rainfall during the growing season [83]. This total volume of water represents less than $8 \%$ of the daily water consumption by Minneapolis [84], so it is not likely that water would be a limiting factor. Estimated total $\mathrm{CO}_{2}$ emissions are 154,000 $\mathrm{kg}$ [80], less than $10 \%$ of the importation scenario (Fig. 4). Total human labor requirements, assuming an average of 2 person-hours $/ \mathrm{m}^{2}$ (conservatively assumed to be one-third lower than mean values for residential gardens reported in [43]) would exceed 427,300 person-hours. If this was paid labor and workers received \$11.00/hour (current minimum wage in Minneapolis), total labor costs would exceed $\$ 4.7$ million, several times higher than the total cost (production + transportation) of importing lettuce from California. The high turnover of commercial urban farms in Minneapolis and Saint Paul attests to the difficult economic barriers to small-scale urban production. As shown in a recent analysis for Sydney [43], human labor would likely be the limiting factor constraining the scaling up of lettuce production through outdoor UA, combined with the lack of production during the winter months.

\subsection{Indoor UA lettuce production (Vertical Farm)}

If the 1900 metric tons of lettuce were to be produced entirely through indoor UA, year-round lettuce demand could be supplied on only 1 hectare [85]. Total water demand for this crop would be approximately $38,000 \mathrm{~m}^{3}$ [86]. Energy demand for lighting and heating would be approximately $350 \mathrm{~kW}$, and heating would require approximately 388,000 therms [87]. Based on current energy infrastructure of the local utility, this energy use would generate 3,168,000 $\mathrm{kg} \mathrm{CO}_{2}$ /year, nearly double that of the importation scenario (Fig. 4), at an annual utilities cost of $\$ 580,000$ [87]. As the utility shifts to more renewable energy production (coal currently accounts for $40 \%$ of electricity production in Minnesota), $\mathrm{CO}_{2}$ production would decrease. 
Human labor requirements would depend on the degree of automation, but we estimate a requirement of 42,000 person-hours/year based on one local indoor production facility [88].

The capital costs of indoor production can be extremely high, requiring products to be sold at premium prices to restaurants and high-end grocery stores. Scaling up local lettuce production would quickly saturate the market for premium lettuce, constraining revenue for this industry. Illustrative of the economic challenges of indoor production, a large ( $0.8 \mathrm{ha}) \mathrm{com}$ mercial aquaponics facility in Saint Paul that has previously received large local government subsidies, recently lost the support of its corporate backer due to not meeting business expectations and is in the process of shutting down [88]. Indoor production of lettuce to meet the demand of Minneapolis-Saint Paul is certainly feasible in terms of space and water requirements, but at a high energy and financial cost.

A supply chain disruption such as a severe drought in California, or a steep rise in petroleum prices that would raise transportation costs, could make UA production (both indoor and outdoor) more economically favorable. However, under current economic conditions, both indoor and outdoor UA struggle to compete with the relatively low production costs of largescale commercial lettuce production. Aside from economic challenges, it is not clear that local production of lettuce is inherently more environmentally sustainable than importation under current conditions (Fig. 4). This analysis illustrates the importance of considering multiple metrics in assessing sustainability of UA.

\section{CONCLUSION}

Would a sustainable city be self-sufficient in food production? Modernist visions of sustainable cities suggest that this is both possible and desirable, but neither of these claims is self-evident. Self-sufficiency for at least some fruit and vegetable crops may be possible, but would likely require strong governmental social or economic incentives, such as in the U.S. Victory Garden program or Cuba's UA initiatives. However, even if self-sufficiency for certain crops is possible, it may not be desirable. Having a resilient food system requires redundancies to buffer against disruptions due to weather, pests, or other factors, and importing food from a variety of locations is one way to do that.

Meeting caloric and protein requirements of urban residents through UA is a much more daunting task, and the bioenergetic and economic feasibility has yet to be demonstrated. The production of animal protein (e.g. fish and chicken) through UA is likely to rely on imported animal feed, or if produced locally, would be competing for resources with food for direct human consumption. Shifting the bulk of food production for urban residents from rural areas to cities would require a dramatic change in the economic playing field, such as a drastic rise in fossil fuel costs that makes long-distance transportation economically prohibitive. Even then, the space, water, and energy requirements of agricultural production in cities would be in direct competition for other human uses, which would further drive up the cost of urban food production.

If self-sufficiency is not the objective of UA, then what is the optimal extent of UA in a sustainable city? The conceptual framework we have presented in this paper is meant to be a guide in exploring this question. Sustainability should necessitate using resources that are abundant while conserving limiting resources. The context of resource availability will differ from one city to another; and therefore, the metrics by which the sustainability of UA should be assessed will necessarily be context-dependent. For some cities, optimization of water use may be the driving factor, while for others, UA may capitalize on abundant ambient precipitation. UA in some cities with high labor costs may require optimization of human labor inputs, 
while in other cities with abundant human labor, UA may be a good source of jobs. The high value of real estate in some cities may drive UA to optimize spatial footprints in some cities, whereas in some post-industrial cities, the goal of UA may be to repurpose vacant land. Economic factors will play a central role in shaping the types of UA that develop in a given city, although some of the social benefits, as well as the cost of pollution, may not be accounted for in a free-market economy. Thus, local governments, non-profits, and other organizations have an important role to play in balancing the societal and environmental benefits and costs of UA.

The ecologist Eugene Odum referred to cities as 'parasites on the landscape' [89] since they rely on imports of food from, and the exportation of pollution to the hinterlands. Odum went on to note that parasites do not live long if they kill or damage their host. Moving cities towards sustainability is critical for the future of humanity, but the extent to which this requires self-sufficiency at the local scale is an open question. The extent to which cities can, or should, be self-sufficient in food production, is a simple question with a complex answer, we argue, with the answer depending on the socio-environmental context of each city. The role of urban agriculture in a sustainable city requires critical analysis, and the framework presented here offers one approach to this task.

\section{ACKNOWLEDGEMENTS}

GES thanks colleagues at the University of Minnesota Institute on the Environment for providing feedback on these ideas. This study was supported in part by a National Science Foundation CAREER award (award number 1651361) to GES. RM thanks his PhD advisors, Romina Rader and Paul Kristiansen, under whose supervision work that forms part of this paper was carried out, and acknowledges the funding provided in the form of an Australian Postgraduate Award and University of New England completion scholarship.

\section{REFERENCES}

[1] Burger, J.R., Allen, C.D., Brown, J.H., Burnside, W.R., Davidson, A.D., Fristoe, T.S., Hamilton, M.J., Mercado-Silva, N., Nekola, J.C., Okie, J.G. \& Zuo, W., The macroecology of sustainability. PLoS Biol, 10(6), p. e1001345, 2012. https://doi.org/10.1371/ journal.pbio.1001345

[2] Rees, W. \& Wackernagle, M., Urban ecological footprints: Why cities cannot be sustainable-and why they are a key to sustainability. Environmental Impact Assessment Review, 16(4-6), pp. 223-248, 1996. https://doi.org/10.1016/s0195-9255(96)00022-4

[3] Weber, C.L. \& Matthews, H.S., Quantifying the global and distributional aspects of American household carbon footprint. Ecological Economics, 66(2-3), pp. 379-391, 2008. https://doi.org/10.1016/j.ecolecon.2007.09.021

[4] Rothwell, A., Ridoutt, B., Page, G. \& Bellotti, W., Environmental performance of local food: trade-offs and implications for climate resilience in a developed city. Journal of Cleaner Production, 114, pp. 420-430, 2016. https://doi.org/10.1016/j. jclepro.2015.04.096

[5] Born, B. \& Purcell, M., Avoiding the local trap: Scale and food systems in planning research. Journal of Planning Education and Research, 26(2), pp. 195-207, 2006. https://doi.org/10.1177/0739456x06291389

[6] Nogeire-McRae, T., Ryan, E.P., Jablonski, B.B.R., Carolan, M., Arathi, H.S., Brown, C.S., Saki, H.H., McKeen, S., Lapansky, E. \& Schipanski, M.E., The role of urban agriculture in a secure, healthy, and sustainable food system. BioScience, 68, pp. 748-759, 2018. https://doi.org/10.1093/biosci/biy071 
[7] Harrison, J.L., Pesticide Drift and the Pursuit of Environmental Justice, MIT Press, 2011.

[8] Goddard, M.A., Dougill, A.J. \& Benton, T.G., Scaling up from gardens: Biodiversity conservation in urban environments. Trends in Ecology and Evolution, 25, pp. 90-98, 2010. https://doi.org/10.1016/j.tree.2009.07.016

[9] Susca, T., Gaffin, S.R. \& Dell'Osso, G.R., Positive effects of vegetation: urban heat island and green roofs. Environmental Pollution, 159(8-9), pp. 2119-2126, 2011. https://doi.org/10.1016/j.envpol.2011.03.007

[10] Armstrong, D., A survey of community gardens in upstate New York: Implications for health promotion and community development. Health Place, 6(4), pp. 319-327, 2009. https://doi.org/10.1016/s1353-8292(00)00013-7

[11] de Zeeuw, H.R., Veenhuizen, V. \& Dubbeling, M., The role of urban agriculture in building resilient cities in developing countries. Journal of Agricultural Science, 149(S1), pp. 153-163, 2011. https://doi.org/10.1017/s0021859610001279

[12] Mincyte, D. \& Dobernig, K., Urban farming in the North American metropolis: rethinking work and distance in alternative food networks. Environment Planning A: Economy and Space, 48, pp. 1767-1786, 2016. https://doi. org/10.1177/0308518x16651444

[13] McClintock, N., Why farm the city? Theorizing urban agriculture through a lens of metabolic rift? Cambridge Journal of Regions Economy and Society, 3(2), pp. 191-207, 2010. https://doi.org/10.1093/cjres/rsq005

[14] Turner, B., Embodied connections: Sustainability, food systems and community gardens. Local Environment, 16(6), pp. 509-522, 2011. https://doi.org/10.1080/1354 9839.2011.569537

[15] Frumkin, H., Healthy places: Exploring the evidence. American Journal of Public Health, 93, pp. 1451-1456, 2003. https://doi.org/10.2105/ajph.93.9.1451

[16] Goodman, W. \& Minner, J., Will the urban agricultural revolution be vertical and soilless? A case study of controlled environment agriculture in New York City. Land Use Policy, 83, pp. 160-173, 2019. https://doi.org/10.1016/j.landusepol.2018.12.038

[17] Turner, W., Nakamura, T. \& Dinetti, M., Global urbanization and the separation of humans from nature. BioScience, 54(6), p. 585, 2004. https://doi.org/10.1641/00063568(2004)054[0585:guatso]2.0.co;2

[18] McCormack, L.A., Laska, M.N., Larson, N.I. \& Story, M., Review of the nutritional implication of farmers' markets and community gardens: A call for evaluation and research efforts. Journal of the American Dietetic Association, 110(3), pp. 399-408, 2010. https://doi.org/10.1016/j.jada.2009.11.023

[19] Boeing, H., Bechthold, A., Bub, A., Ellinger, S., Haller, D., Kroke, A., Leschik-Bonnet, E., Muller, M.J., Oberritter, H., Shulze, M., Stehle, P. \& Watzl, B., Critical review: Vegetables and fruit in the prevention of chronic diseases. European Journal of Nutrition, 51(6), pp. 637-663, 2012. https://doi.org/10.1007/s00394-012-0380-y

[20] Joye, Y., Architectural lessons from environmental psychology: The case of biophilic architecture. Review of General Psychology, 11(4), pp. 305-328, 2007. https://doi. org/10.1037/1089-2680.11.4.305

[21] Ulrich, R., Evidence-based health-care architecture. Lancet, 368(12), pp. S38-S39, 2006. https://doi.org/10.1016/s0140-6736(06)69921-2

[22] Dimitri, C., Olberholtzer, L. \& Pressman, A., Urban agriculture: Connecting producers with consumers. British Food Journal, 118, pp. 603-617, 2016. https://doi.org/10.1108/ bfj-06-2015-0200 
[23] Caldeyro-Stajano, M., Simplified hydroponics as an appropriate technology to implement food security in urban agriculture. Practical Hydroponics Greenhouses, 76, pp. 1-6, 2004.

[24] Voicu, I. \& Been, V., The effect of community gardens on neighboring property values. Real Estate Economics, 36(2), pp. 241-283, 2008. https://doi.org/10.1111/j.15406229.2008.00213.x

[25] Vitiello, D. \& Wolf-Powers, L., Growing food to grow cities? The potential of agriculture for economic and community development in the urban United States. Community Development Journal, 49(4), pp. 508-523, 2014. https://doi.org/10.1093/cdj/bst087

[26] Cleveland, D.A. et al., The potential for urban household vegetable gardens to reduce greenhouse gas emissions. Landscape and Urban Planning, 157, pp. 365-374, 2017. https://doi.org/10.1016/j.landurbplan.2016.07.008

[27] Al-Chalabi, M., Vertical farming: Skyscraper sustainability? Sustainable Cities and Society, 18, pp. 74-77, 2015. https://doi.org/10.1016/j.scs.2015.06.003

[28] Harada, Y., Whitlow, T.H., Walter, M.T., Bassuk, N.L., Russell-Anelli, J. \& Schindelbeck, R.R., Hydrology of the Brooklyn Grange, an urban rooftop farm. Urban Ecosystems, 21(4), pp. 673-689, 2018. https://doi.org/10.1007/s11252-018-0749-7

[29] Metson, G.S. \& Bennett, E.M., Phosphorus cycling in Montreal's food and urban agricultural systems. PLoS One, 10(3), p. e0120726, 2015.

[30] Dewaelheyns, V., Elsen, A., Vandendriessche, H. \& Gulinck, H., Garden management and soil fertility in Flemish domestic gardens. Landscape and Urban Planning, 116, pp. 25-35, 2013. https://doi.org/10.1016/j.landurbplan.2013.03.010

[31] Small, G., Shrestha, P. \& Kay, A., The fate of compost-derived phosphorus in urban gardens. International Journal of Design \& Nature and Ecodynamics, 13(4), pp. 415-422, 2018. https://doi.org/10.2495/dne-v13-n4-415-422

[32] Lin, B.B., Philpot, S.M., \& Jha, S., The future of urban agriculture and biodiversityecosystem services: Challenges and next steps. Basic and Applied Ecology, 16(3), pp. 189-201, 2015.

[33] Isaacs, R., Tuell, J., Fielder, A., Gardiner, M. M., \& Landis, D., Maximising arthropodmediated ecosystem services in agricultural landscapes: The role of native plants, Frontiers in Ecology and the Environment, 7, pp. 196-203, 2009.

[34] Clinton, N., Stuhlmacher, M., Miles, A., Uludere Aragon, N., Wagner, M., Georgescu, M., Herwig, C. \& Gong, P., A global geospatial ecosystem services estimate of urban agriculture. Earth's Future, 6, pp. 40-60, 2018. https://doi.org/10.1002/2017ef000536

[35] Keeler, B.L., Hamel,P., McPhearson, T., Hamman, M.H., Donahue, M.L., Meza Prado, K.A., Arkema, K.K., Bratman, G.N., Brauman, K.A., Finlay, J.C., Guerry, A.D., Hobbie, S.E., Johnson, J.A., MacDonald, G.K., McDonald, R.I., Neverisky, N. \& Wood, S.A., Socialecological and technological factors moderate the value of urban nature, Nature Sustainability, 2(1), p. 29, 2019. https://doi.org/10.1038/s41893-018-0202-1

[36] Martelozzo, F., Landry, J.S., Plouffe, D., Seufert, V., Rowhani, P. \& Ramankutty, N., Urban agriculture: A global analysis of the space constraint to meet urban vegetable demand. Environmental Research Letters, 9(6), p. 064025, 2014. https://doi. org/10.1088/1748-9326/9/6/064025

[37] Stanhill, G., An urban agro-ecosystem: The example of nineteenth-century Paris. Agro-Ecosystems, 3, pp. 269-284, 1976. https://doi.org/10.1016/0304-3746(76)90130-x

[38] Nixon, P.A. \& Ramaswami, A., Assessing current local capacity for agrifood production to meet household demand: Analyzing select food commodities across 377 U.S. Metropolitan Areas. Environmental Science and Technology, 52(18), pp. 10511-10521, 2018. https://doi.org/10.1021/acs.est.7b06462 
[39] Grewal, S.S. \& Grewal, P.S., Can cities become self-reliant in food? Cities, 29(1), pp. 1-11, 2012. https://doi.org/10.1016/j.cities.2011.06.003

[40] Rodriguez, O., London Rooftop Agriculture: A Preliminary Estimate of Productive Potential, Master Thesis, Cardiff: Welsh School of Architecture, 2009.

[41] Caplow, T., Building integrated agriculture: philosophy and practice. In Urban Futures 2030: Urban Development and Urban Lifestyles of the Future, ed. Heinrich Böll Foundation, Heinrich-Böll-Stiftung, Berlin, Germany, pp. 54-58, 2009.

[42] Kong, A.Y.Y., Rosenzweig, C. \& Arky, J., Nitrogen dynamics associated with organic and inorganic inputs to substrate commonly used on rooftop farms. HortScience, 50(6), pp. 806-813, 2015. https://doi.org/10.21273/hortsci.50.6.806

[43] McDougall, R., Kristiansen, P., \& Rader, R., Small-scale urban agriculture results in high yields but requires judicious management of inputs to achieve sustainability. Proceedings of the National Academy of Sciences USA, 116(1), pp. 129-134, 2019. https://doi.org/10.1073/pnas.1809707115

[44] Despommier, D., The rise of vertical farms. Scientific American, 301(5), pp. 80-87, 2009. https://doi.org/10.1038/scientificamerican1109-80

[45] Artmann, M. \& Sartison, K., The role of urban agriculture as a nature-based solution: A review for developing a systematic assessment framework. Sustainability, 10(6), p. 1937, 2018. https://doi.org/10.3390/su10061937

[46] Ramaswami, A., Boyer, D., Nagpure, A.S., Fang, A., Bogra, S., Bakshi, B., Cohen, E. $\&$ Rao-Ghorpade, A., An urban systems framework to assess the trans-boundary foodenergy-water nexus: implementation in Delhi, India. Environmental Research Letters, 12(2), p. 025008, 2017. https://doi.org/10.1088/1748-9326/aa5556

[47] Dmitri, C., Oberholtzer, L. \& Pressman, A., Urban agriculture: Connecting producers with consumers. British Food Journal, 118, pp. 603-617, 2016. https://doi.org/10.1108/ bfj-06-2015-0200

[48] Despommier, D., Farming up the city: the rise of urban vertical farms. Trends in Biotechnology, 31(7), pp. 388-389, 2013. https://doi.org/10.1016/j.tibtech.2013.03.008

[49] Cook, R.L. \& Calvin, L., Greenhouse tomatoes change the dynamics of the North American fresh tomato industry. U.S. Department of Agriculture Economic Research Report, 2, pp. 1-11, 2005.

[50] Astee, L.Y. \& Kishnani, N., Building integrated agriculture: Utilising rooftops for sustainable food crop cultivation in Singapore. Journal of Green Building, 5(2), pp. 105-113, 2010. https://doi.org/10.3992/jgb.5.2.105

[51] Sauerborn, J., Skyfarming: An alternative to horizontal croplands. Resource Magazine, 18, pp. 938-941, 2011.

[52] Ellingsen, E. \& Despommier, D., The vertical farm: The origin of a 21st century architectural typology. CTBUH Journal, 3, pp. 26-34, 2008.

[53] Delor, M., Current State of Building-Integrated Agriculture, Its Energy Benefits and Comparisons with Green Roofs, University of Sheffield, Sheffield, UK, 2011.

[54] Reinhardt, W., Albright, L. \& de Villiers, D.S., Energy investments and $\mathrm{CO}_{2}$ emissions for fresh produce imported into New York State compared to the same crops grown locally. New York State Energy Research and Development Authority, pp. 8-10, 2008.

[55] Specht, K., Siebert, R., Hartmann, I., Freisinger, U.B., Sawicka, M., Werner, A., Thomaier, S., Henckel, D., Walk, H. \& Dierich, A., Urban agriculture of the future: An overview of sustainability aspects of food production in or on buildings. Agriculture and Human Values, 31(1), pp. 33-51, 2014. https://doi.org/10.1007/s10460-013-9448-4 
[56] Bhanoo, S., Vertical farms will be big, but for whom? Indoor farming might help feed millions, or at least make millions, https://www.fastcompany.com/3039087/verticalfarms-will-be-big-but-for-who (accessed 7 May 2019).

[57] de Nijs, B., Does vertical farming make sense? Hortidaily.com, https://www.hortidaily. com/article/35974/Does-vertical-farming-make-sense/ (accessed 7 May 2019).

[58] Vogl, C.R., Axmann, P. \& Vogl-LuKasser, B., Urban organic farming in Austria with the concept of Selbstemte ('self-harvest'): An agronomic and socio-economic analysis. Renewable Agriculture and Food Systems, 19(2), pp. 67-79, 2004. https://doi. org/10.1079/rafs200062

[59] Ackerman, K., Dahlgren, E. \& Xue, X., Sustainable Urban Agriculture: Confirming Viable Scenarios for Production, New York State Energy Research and Development Authority: Albany, New York, 2013.

[60] Taylor, J.R. \& Lovell, S.T., Urban home food gardens in the Global North: research traditions and future directions. Agriculture and Human Values, 31(2), pp. 85-305, 2014. https://doi.org/10.1007/s10460-013-9475-1

[61] Swaney, D.P., Howarth, R.W. \& Hong, B., Nitrogen use efficiency and crop production: Patterns of regional variation in the United States, 1987-2012, Science of the Total Environment, 635, pp. 498-511, 2018. https://doi.org/10.1016/j.scitotenv.2018.04.027

[62] Suh, S. \& Yee, S., Phosphorus use-efficiency of agriculture and food system in the U.S. Chemosphere, 84(6), pp. 806-813, 2011. https://doi.org/10.1016/j.chemosphere.2011.01.051

[63] Hoornweg, D. \& Bhada-Tata, P., What a Waste - A Global Review of Solid Waste Management, World Bank Urban Development Series Knowledge Papers, 15, 2012.

[64] Fletcher, T.D., Deletic, A., Mitchell, V.G. \& Hatt, B.E., Reuse of urban runoff in Australia: A review of recent advances and remaining challenges. Journal of Environmental Quality, 37(5_Supplement), pp. S-116, 2008. https://doi.org/10.2134/jeq2007.0411

[65] Barthel, S., Parker, J. \& Ernstson, H., Food and green space in cities: A resilience lens on gardens and urban environmental movements. Urban Studies, 52(7), pp. 1321-1338, 2015. https://doi.org/10.1177/0042098012472744

[66] Barthel, S., Folke, C. \& Colding, J., Social-ecological memory in urban gardens-Retaining the capacity for management of ecosystem services. Global Environmental Change, 20(2), pp. 255-265, 2010. https://doi.org/10.1016/j.gloenvcha.2010.01.001

[67] Endres, A.B. \& Endres, J.M., Homeland security planning: What victory gardens and Fidel Castro can teach us in preparing for food crises in the United States. Food and Drug Law Journal, 64, pp. 405-439, 2009.

[68] Warwick, H., Cuba's organic revolution. Forum for Applied Research and Public Policy, 16, pp. 54-58, 2001.

[69] Brown, M.E., Antle, J.M., Backlund, P., Carr, E.R., Easterling, W.E., Walsh, M.K., Ammann, C., Attavanich, W., Barrett, C.B., Bellemare, M.F., Dancheck, V., Funk, C., Grace, K., Ingram, J.S.I., Jiang, H., Maletta, H., Mata, T., Murray, A., Ngugi, M., Ojima, D., O’Neill, B. \& Tebaldi, C., Climate Change, Global Food Security, and the U.S. food system. U.S. Department of Agriculture, 2015.

[70] Ostrum, E., Polycentric systems for coping with collective action and global environmental change. Global Environmental Change, 20(4), pp. 550-557, 2010. https://doi. org/10.1016/j.gloenvcha.2010.07.004

[71] Qui, G., Li, H., Zhang, Q., Chen, W., Liang, X. \& Li, X., Effects of evapotranspiration on mitigation of urban temperature by vegetation and urban agriculture. Journal of Integrative Agriculture, 12(8), pp. 1307-1315, 2013. https://doi.org/10.1016/s2095-3119(13)60543-2 
[72] Egerer M.H., Lin, B.B., Threlfall, C.G. \& Kendal, D., Temperature variability influences urban garden plant richness and gardener water use behavior, but not planting decisions. Science of the Total Environment, 646, pp. 111-120, 2019. https://doi.org/10.1016/j. scitotenv.2018.07.270

[73] Barthel, S. \& Isendahl, C., Urban gardens, agriculture, and water management: Sources of resilience for long-term food security in cities. Ecological Economics, 86, pp. 224-234, 2013. https://doi.org/10.1016/j.ecolecon.2012.06.018

[74] Somerville, C. \& Ferrand, C., Aquaponics in Gaza, Field Exchange 46: Special Focus on Urban Food Security \& Nutrition, September 2013.

[75] Foskett, D., Food Security and Small-Scale Aquaponics: A Case Study on the Northern Mariana Island of Rota, M.A. Thesis, University of Oregon, 2014.

[76] Moore, A., This local agtech startup wants you to forget everything you know about farming. Upstate Business Journal, Online: https://upstatebusinessjournal.com/thislocal-agtech-startup-wants-you-to-forget-everything-you-know-about-farming/, 5 March 2018 (accessed 7 May 2019).

[77] Agricultural Marketing Research Center, Lettuce. Online: https://www.agmrc.org/commodities-products/vegetables/lettuce (accessed 7 May 2019).

[78] Pioneer Press, Census: Minneapolis-St. Paul metro adds more than 250,000 residents since 2010. Online https://www.twincities.com/2018/03/22/census-minneapolis-stpaul-metro-adds-more-than-250000-residents-since-2010/ (accessed 15 May 2019).

[79] University of California Cooperative Extension, Sample production costs for wrapped iceberg lettuce sprinkler irrigated-40-inch beds: Central Coast, 2010. Online: https:// coststudyfiles.ucdavis.edu//uploads/cs_public/a4/bb/a4bb20f0-4bfe-404e-b47eb7a634ca80b5/2010lettuce_wrap_cc.pdf (accessed 15 May 2019).

[80] Goldstein, B.P., Hauschild, M.Z., Fernandez, J. \& Birkved, M., Testing the environmental performance of urban agriculture as a food supply in northern climates. Journal of Cleaner Production, 135, pp. 984-994, 2016. https://doi.org/10.1016/j. jclepro.2016.07.004

[81] Ronan, D., Cost of operating a truck up $6 \%$ to $\$ 1.69$ per mile, ATRI report says, Transpor Topics, Online: https://www.ttnews.com/articles/cost-operating-truck-6-169-mile-atrireport-says (accessed 15 May 2019).

[82] City of Minneapolis Land Capacity Analysis, 2010. Online: http://www.minneapolismn.gov/www/groups/public/@ cped/documents/webcontent/convert_261135.pdf, (accessed 15 May 2019).

[83] U.S. Climate Data. Online: https://www.usclimatedata.com/climate/minneapolis/minnesota/united-states/usmn0503, (accessed 15 May 2019).

[84] Minneapolis Water Treatment and Distribution Services. Online: http://www.minneapolismn.gov/publicworks/water/water_waterfacts (accessed 15 May 2019).

[85] Kubota, C., Controlled Environment Agriculture for Urban Food Production, 2018 Urban Food Systems Symposium, Minneapolis, MN, 2018.

[86] Barbosa, G.L., Gadelha, F.D.A., Kublick, N., Proctor, A., Reichelm, L., Weissinger, E., Wohlleb, G.M. \& Halden, R.U., Comparison of land, water, and energy requirements of lettuce grown using hydroponics vs. conventional agricultural methods. International Journal of Environmental Research and Public Health, 12(6), pp. 6879-6891, 2015. https://doi.org/10.3390/ijerph120606879

[87] Xcel Energy, Carbon dioxide emission intensities, 2018. Online: https://www.xcelenergy.com/staticfiles/xe-responsive/Environment/Carbon/Xcel-Energy-Carbon-Dioxide-Emission-Intensities.pdf (accessed 15 May 2019). 
[88] Riley, M., Pentair shutting down urban organics aquaponics facility in St. Paul. Minneapolis/St. Paul Business Journal, 15 May 2019, Online: https://www.bizjournals.com/twincities/news/2019/05/15/pentair-shutting-down-urban-organics-aquaponics.html (accessed 20 May 19).

[89] Odum, E. P., Ecology and Our Endangered Life-Support Systems, Sunderland, MA: Sinauer Associates, 1989.

[90] CoDrye, M., Fraser, E.D.G. \& Landman, K., How does your garden grow? An empirical evaluation of the costs and potential of urban gardening. Urban Forestry \& Urban Greening, 14(1), pp. 72-79, 2015. https://doi.org/10.1016/j.ufug.2014.11.001

[91] Haberman, D., Gillies, L., Canter, A., Rinner, V., Pancrazi, L. \& Martellozzo, F., The potential of urban agriculture in Montreal: A quantitative assessment. ISPRS International Journal of GeoInformation, 3(3), pp. 1101-1117, 2014. https://doi.org/10.3390/ ijgi3031101

[92] Hara, Y., Murakami, A., Tsuchiya, K., Palijon, A.M. \& Yokohari, M., A quantitative assessment of vegetable farming on vacant lots in an urban fringe area in Metro Manila: Can it sustain long-term vegetable demand? Applied Geography, 41, pp. 195-206, 2013. https://doi.org/10.1016/j.apgeog.2013.04.003

[93] MacRae, R., Gallant, E., Patel, S., Michalak, M., Bunch, M. \& Schaffner, S., Could Toronto provide $10 \%$ of its fresh vegetable requirements from within its own boundaries? Matching consumption requirements with growing spaces, Journal of Agriculture, Food Systems, and Community Development, 1(2), pp. 105-127, 2010. https://doi. org/10.5304/jafscd.2010.012.008

[94] Orsini, F., Gasperi, D., Marchetti, L., Piovene, C., Draghetti, S., Ramazzotti, S., Bazzocchi, G. \& Gianquinto, G., Exploring the production capacity of rooftop gardens (RTGs) in urban agriculture: the potential impact on food and nutrition security, biodiversity and other ecosystem services in the city of Bologna. Food Security, 6(6), pp. 781-792, 2014. https://doi.org/10.1007/s12571-014-0389-6

[95] Johnson, M.S., Lathuillière, M.J., Tooke, T.R. \& Coops, N.C., Attenuation of urban agricultural production potential and crop water footprint due to shading from buildings and trees. Environmental Research Letters, 10(6), pp. 1-11, 2015. https:// doi.org/10.1088/1748-9326/10/6/064007

[96] Lee, G.G., Lee, H.W. \& Lee, J.H., Greenhouse gas emission reduction effect in the transportation sector by urban agriculture in Seoul, Korea. Landscape and Urban Planning, 140, pp. 1-7, 2015. https://doi.org/10.1016/j.landurbplan.2015.03.012

[97] Hara, Y., McPhearson, Sampei, T. \& McGrath, B., Assessing urban agriculture potential: A comparative study of Osaka, Japan and New York City, United States, Sustainability Science, 13(4), pp. 937-952, 2018. https://doi.org/10.1007/s11625018-0535-8

[98] Sioen, G.B., Sekiyama, M., Terada, T. \& Yokohari, M., Post-disaster food and nutrition from urban agriculture: A self-sufficiency analysis of Nerima ward, Tokyo. International Journal of Environmental Research and Public Health, 14(7), p. 748, 2017. https://doi.org/10.3390/ijerph14070748

[99] Clark, K.H. \& Nicholas, K.A., Introducing urban food forestry: A multifunctional approach to increase food security and provide ecosystem services. Landscape Ecology, 28(9), pp. 1649-1669, 2013. https://doi.org/10.1007/s10980-013-9903-z

[100] Colosanti, K. \& Hamm, M.W., Assessing the local food supply capacity of Detroit, Michigan. Journal of Agriculture, Food Systems, and Community Development, 1(2), pp. 41-58, 2010. https://doi.org/10.5304/jafscd.2010.012.002 